\title{
ON DEGENERATE TYPES OF SCAPULAR AND PELVIC ARCHES IN THE LACERTILIA.
}

\section{E. D. COPE. 1}

Paleontology has rendered it possible to assert that the rudimental condition and absence of limbs observed in many genera of Lacertilia are a result of retrogressive evolution or degeneracy. ${ }^{2}$ These degenerate conditions are seen in genera of the superfamilies Diploglossa, Leptoglossa, Annielloidea, and Amphisbænia. In the remaining six superfamilies such conditions have not been observed, except in such cases as Sitana (Agami$\mathrm{d}$ ), where a single digit is absent from the posterior foot. Certain questions respecting the origin of the degenerate forms naturally arise. One of these is, Is the manner of degeneracy in each superfamily or family characteristic of it, and different from that obtaining in other families? Secondly, What is the order of degeneracy? what parts disappear first and which are longest persistent? Thirdly, Can any relation between the manner of degeneracy and the life history of the genus be traced? The following investigation was undertaken with the object of throwing light, if possible, on these points. The material at my disposal has not been sufficient to enable me to answer any of these questions in a final way, but some information has been gained which will aid in future research. Fifteen species have been examined, six of which belong to the Diploglossa, five to the Leptoglossa, one to the Annielloidea, and three to the Amphisbænoidea. All of the families known to possess degenerate types are represented, excepting the Gerrhosauridæ and the Dibamidæ, of which the former has but five genera, two of which are degenerate, and the latter but one genus. Thus a general view of the subject has been obtained. Of these species eight are described for the first time; viz. two Diploglossa, four Leptoglossa, one Annielloidea, and two

1 Read before the U. S. National Academy of Sciences, November I0, I891.

2 Origin of the Fittest, 1887 , p. 337 . 
[VoL. VII.

Amphisbænoidea. Additions to and corrections of descriptions already given of some of the other species are also made.

The following table represents the digital characters and distribution of the known genera of Lacertilia with defective limbs

\begin{tabular}{|c|c|c|c|c|c|}
\hline & \multicolumn{3}{|c|}{ DipLoglossA } & \multicolumn{2}{|r|}{ LEPTO } \\
\hline & Pygopodidæ & Zonuridæ & Anguidæ & Teidæ & Gerrhosauridæ \\
\hline $\begin{array}{l}\text { I. Limbs, two pair } \\
\text { a. Digits } 5-4\end{array}$ & & & & Tejus & \\
\hline b. Digits 4-5 & & & & $\begin{array}{l}\text { Tretioscineus } \\
\text { Micrablepharus } \\
\text { Gymopthalmus }\end{array}$ & \\
\hline c. Digits $4-4$ & & & Sauresia & Scolecosaurus & Saurophis \\
\hline \multicolumn{6}{|l|}{ d. Digits 4-3 } \\
\hline \multicolumn{6}{|l|}{ e. Digits 3-4 } \\
\hline$f$. Digits 3-3 & & & & Microdactylus & \\
\hline$g$. Digits $3-2$ & & & & Herpetochalcis & \\
\hline \multicolumn{6}{|l|}{ h. Digits 2-4 } \\
\hline \multicolumn{6}{|l|}{ i. Digits 2-3 } \\
\hline \multicolumn{6}{|l|}{$j$. Digits $2-2$} \\
\hline $\begin{array}{l}k . \text { One or both } \\
\text { monodactyle }\end{array}$ & & Chamæsaura & Panolopus & $\begin{array}{l}\text { Cophias } \\
\text { Ophiognomon }\end{array}$ & Cætia \\
\hline II. Fore limbs only & & & & Propus (digits o) & \\
\hline III. Hind limbs only & $\begin{array}{l}\text { Pygopus } \\
\text { Cryptodelma } \\
\text { Delma } \\
\text { Pletholax } \\
\text { Aprasia } \\
\text { Lialis }\end{array}$ & Mancus & $\begin{array}{l}\text { Pseudopus } \\
\text { Opheodes } \\
\text { Hyalosaurus }\end{array}$ & & \\
\hline IV. No limbs & & & $\begin{array}{l}\text { Opheosaurus } \\
\text { Dopasia } \\
\text { Anguis }\end{array}$ & & \\
\hline
\end{tabular}


and feet. From this it is evident that the greater number belong to the Leptogloss family of the Scincidæ, whose habitat is the rocky or sandy desert regions of Africa, Western Asia, and Australia.

\begin{tabular}{|c|c|c|c|c|c|}
\hline GLOSSA & & & & $\begin{array}{c}\text { ANNIEL- } \\
\text { LOIDEA }\end{array}$ & Annulati. \\
\hline Scincidæ & Acontüdæ & Dibamidæ & Anelytropidæ & Anniellidæ & \\
\hline \multicolumn{6}{|l|}{ Hagria } \\
\hline \multicolumn{6}{|l|}{$\begin{array}{l}\text { Heteropus } \\
\text { Ristella } \\
\text { Menetia } \\
\end{array}$} \\
\hline \multicolumn{6}{|l|}{$\begin{array}{l}\text { Menetia } \\
\text { Gongyloseps } \\
\text { Chiamela } \\
\text { Rhinoscineus } \\
\text { Tetradactylus } \\
\text { Miculia } \\
\text { Chalcidoseps } \\
\text { Blepharactisis } \\
\text { Sphenops } \\
\end{array}$} \\
\hline \multicolumn{6}{|l|}{ Zygnopsis } \\
\hline \multicolumn{6}{|l|}{ Allodactylus } \\
\hline $\begin{array}{l}\text { Tridentulus } \\
\text { Chalcides } \\
\text { Hemiergis } \\
\text { Siaphus } \\
\text { Phaneropis } \\
\text { Sepomorphus } \\
\text { Sphenoscineus } \\
\text { Sepsina } \\
\end{array}$ & Nessia & & & & \\
\hline \multicolumn{6}{|l|}{ Hemipodium } \\
\hline \multicolumn{6}{|l|}{ Anisoterma } \\
\hline \multicolumn{6}{|l|}{$\begin{array}{l}\text { Lerista } \\
\text { Eumecia } \\
\text { Heteromeles }\end{array}$} \\
\hline \multicolumn{6}{|l|}{$\begin{array}{l}\text { Dimeropus } \\
\text { Chelomeles }\end{array}$} \\
\hline \multirow[t]{2}{*}{$\begin{array}{l}\text { Brachystopus } \\
\text { Oncopus } \\
\text { Brachymeles } \\
\text { Anomalopus } \\
\text { Coloscincus } \\
\text { Furcillus } \\
\text { Dicloniscus } \\
\end{array}$} & Evesia & & & & \\
\hline & & & & & Chirotes (digits 4) \\
\hline $\begin{array}{l}\text { Ollochirus } \\
\text { Dumerlia } \\
\text { Scelotes } \\
\text { Soridia } \\
\text { Podoclonium }\end{array}$ & & Dibamus & & & \\
\hline $\begin{array}{l}\text { Ophioscincus } \\
\text { Herpetosaura } \\
\text { Sepophis } \\
\text { Herpetoseps } \\
\text { Opheomorus }\end{array}$ & $\begin{array}{l}\text { Acontias } \\
\text { Typhlacontias }\end{array}$ & & $\begin{array}{l}\text { Anelytropsis } \\
\text { Feylinia } \\
\text { Typhlosaurus }\end{array}$ & Anniella & $\begin{array}{l}\text { Amphisbæna } \\
\text { Rhineura } \\
\text { Lepidosternum } \\
\text { Trogonophidæ }\end{array}$ \\
\hline
\end{tabular}


In the following pages descriptions of the scapular and pelvic arches of the types referred to are given.

\section{DIPLOGLOSSA.}

\section{ZONURIDÆ.}

Mancus macrolepis Cope, from Natal. Pl. XIII, Fig. I. Not previously examined. Scapular and pelvic arches both present. Anterior limbs, none; posterior limb, an externally undivided rudiment. Scapulararch. All the elements present. Sternum supporting three hæmal ribs on each side, deeply emarginate so as to be horseshoe-shaped, with a short posterior prolongation; each branch cartilaginous anteriorly. Suprascapula cartilaginous. Scapula and coracoid confluent, osseous ; procoracoid cartilage. Interclavicle cruciform, with long posterior axis. Pelvic arch. All the elements present, but small and slender. Ilium attached to the distally confluent diapophyses of two vertebræ. Pubes slender, in contact anteriorly. Ischia directed anteriorly, not forming a symphysis, but separated by a median osseous element, which, following Baur, ${ }^{1}$ I call the hypogastroid bone (Fig. I, $c, h g$ ). This is produced anteriorly as a cartilage, which joins the pubes, and posteriorly as a median simple cartilaginous rod. Posterior limb. This is about as long as the pubis and half the ilium. It consists of a femur, distinct but closely apposed tibia and fibula, about three-fifths the length of the femur, and a simple conical tarsal.

\section{Pygopodide.}

Pygopus lepidopus Lacep. Pl. XIII, Fig. 3. Already described in part by Heusinger, ${ }^{2}$ Cuvier, ${ }^{3}$ Müller, ${ }^{4}$ and Fürbringer. ${ }^{5}$ From Australia.

Scapular and pelvic arches present; no anterior, and rudimental posterior limbs. Scapular arch. Elements present except interclavicle. Sternum, a small longitudinally oval car-

1 American Fournal of Morphology, IV, 1891, p. 345; where he names the epigastroid, mesogastroid, and hypogastroid cartilages of the Testudinata.

2 Zeitschr. fïr Organ. Physik., III, h. 5, p. 489.

${ }^{3}$ Régne Animal.

4 Tiedemann u. Treviranus Zeitschr. f. Physiologie, IV, 1831, p. 227.

${ }^{5}$ Die Knochen u. Muskeln der Schlangenähnlichen Saurier, Leipsic, 1870. 
tilage in contact with coracoid cartilages only; supporting two hæmal ribs at its posterior extremity. Clavicles long, slender, extended well anteriorly, simple and in contact distally. Coracoid, procoracoid, and scapula, osseous, confluent. Coracoid cartilage not reaching procoracoid. Pelvic arch. Ilium elongate, proximal half horizontal, parallel with three vertebræ; distal portion decurved and confluent with pubis and ischium. Latter elements both rudimental, widely separated on the median line. Hypogastroid cartilage represented by a slender rod extending posteriorly on each side from the position of the acetabulum. Perhaps these cartilages represent the ischia, but they are possibly present with ischia in Opheodes, q.v. Posterior limb. This consists of femur, tibia and fibula, and four metatarsals, all enclosed in a common integument. It is about as long as the ilium.

My observations on this genus agree with those of Fürbringer.

\section{ANGUIDE.}

Opheodes striatus Spix. Pl. XIII, Fig. 2. Partially described by Müller, l.c., imperfectly figured by Duméril and Bibron, ${ }^{1}$ and well described and figured by Fürbringer. ${ }^{2}$ South America.

Scapular and pelvic arches present; no anterior limbs; posterior limbs present, rudimental.

Scapular arch. All the elements present ; clavicles well developed; distally simple. Interclavicle approximated to them, anchor-shaped, with very short posterior axis, which is widely separated from the sternum. Scapula, coracoid, and procoracoid, osseous, confluent; no coracoid cartilage. Procoracoid cartilage a slender rod, wedged between the interclavicle and the clavicle. Sternum subtriangular, with shallow anterior notch, supporting two hæmal ribs on each side. Pelvic arch. All the elements present, the pubis and ischium not in contact on the median line. Ilium articulating below its middle with the confluent diapophyses of two vertebræ. Pubis about as long as ilium, the distal half rodlike, and separated from its fellow by a space equal to its length. It terminates in a short cartilaginous rod, which is directed for-

1 Erpétologie Générale, Atlas, 1854, Pl. VII, Figs. 3-7.

2 l.c., pp. II and $3^{8 .}$ 
wards (? epigastroid cartilage). The ischium is transverse in position, and somewhat expanded distally, sending forward a membranous sheet to the pubis. Posteriorly it gives origin to a cartilaginous rod (hypogastroid) which speedily joins its fellow, and continues with it as a double median cartilage, terminating acutely. This cartilage resembles that already described in Pygopus, where, however, the two do not meet on the middle line. Posterior limb. This is a little longer than the ilium. It consists of femur, tibia and fibula about two-thirds as long; and tarsal and metatarsal elements, all closely adherent. The former are three in number, and the latter two.

Observations. In the figure by Duméril and Bibron of the scapular arch, the procoracoid is omitted. The pelvis has been drawn from a dried specimen where the inferior arches have been divided and the lateral elements widely separated. The cartilages are not represented.

Ophisaurus ventralis L. Pl. XIII, Fig. 4. Described by Müller, l.c., Duméril and Bibron, ${ }^{1} \mathrm{Cope}^{2}$ (scapular arch in part), Fürbringer ${ }^{3}$ and Shufeldt. ${ }^{4}$ Southern parts of North America east of the Rocky Mountains.

Scapular and pelvic arches present; no anterior limbs; posterior represented by a minute rudiment, which is not visible externally.

Scapular arch. All the elements present, but more or less rudimental. Clavicles well developed, simple, and nearly meeting distally. Scapula cartilaginous, coracoid osseous, with a large cartilage which is produced anteriorly and is continuous with the small cartilaginous procoracoid. Interclavicle posterior to the coracoid cartilages and overlapping the anterior border of the sternum ; its anterior limb very short, the posterior still shorter; sternum transverse, subcrescentic, cartilaginous, not supporting any ribs.

Pelvic arch. Ilium short, proximally in contact with a single vertebra, distally confluent with the rudimental pubis and ischium, which form together an oval plate, entirely lateral in position.

\footnotetext{
1 Erp. Gen., Atlas, VII, Figs. 5-9.

2 Proceed. Acad., Phila., I864, p. 228.

3 l.c., pp. I4, 43, Pl. I, Fig. 8 ; Pl. III, Fig. 36.

4 Proceed. U. S. National Museum, I882, p. 397.
} 
Posterior limb. This is an undivided, short rod of cartilage, which is loosely articulated to the posterior concavity of the pelvic element, thus marking the position of the acetabulum.

Observations. Müller (l.c., 227) erroneously states that the sternum is wanting in this genus. The figure of the scapular arch given by Duméril and Bibron is very defective in proportions. The posterior limb rudiment is not shown in the pelvic arch. This is figured by Schufeldt, but he omits the interclavicle from the scapular arch, as he does also from that of Gerrhonotus multicarinatus (l.c., Figs. 4 and 5). The pelvic elements and limb are well figured by Müller (l.c., Pl. XIX, Fig. 3). Fürbringer's description is good, but he overlooks the rudimental femur.

Pseudopus apus Pallas. Not examined by me, but described by Heusinger, Müller (l.c., Pl. XIX, Fig. 2), and Duméril and Bibron, and Fürbringer. These authors represent the scapular arch as being closely similar to that of Ophisaurus. The pelvic arch differs in the slightly greater development of the hind limb, which besides being minute has a still more minute tibia.

Dopasia GRacilis Gray. Pl. XIII, Fig. 5. From the Himalayas. Not previously studied. Scapular and pelvic arches present, no limbs.

Scapular arch. Interclavicle wanting; clavicles present, osseous, meeting medially. Scapula cartilaginous ; coracoid osseous. A large coracoid cartilage, which is continued proximally into the short and narrow procoracoid cartilage. Sternum without rib connections, of a transversely crescentic form, the convexity anterior, with some ossific deposit at the middle, on each side of the median line.

Pelvic arch. The three elements fused into a single piece, of which the ilium forms a slender proximal part, and the distal elements an oval plate, concave anteriorly, and convex posteriorly; the whole entirely lateral in position, and having a general resemblance to the corresponding parts of Ophisaurus. Ilium short, its proximal extremity in contact with a very robust diapophysis of a single vertebra.

Observations. The absence of the interclavicle justifies the retention of the genus Dopasia Gray, as distinct from Ophisaurus. I have examined two skeletons of the $D$. gracilis, and a half dozen of those of $O$. ventralis. 
Anguis fragilis Linn. Pl. XIII, Fig. 6. Described by Heusinger, l.c., Pl. III, Fig. 9; Müller, l.c. ; and imperfectly figured by Duméril and Bibron, l.c., VII, Figs. 6 and Io. It is well described and figured by Fürbringer, l.c., pp. I4, 42; Pl. I, Fig. 9; Pl. III, Figs. 37, 38. Europe.

Scapular and pelvic arches present; no limbs.

Scapular arch. Interclavicle wanting; other elements present. Sternum roughly transverse diamond-shaped, with the posterior border slightly convex. No costal connections. Ossification slight. Clavicles osseous, slender, directed forward medially, and not quite meeting on the median line. Scapula cartilaginous, coracoid osseous. A large coracoid cartilage, which slightly overlaps that of the other side anteriorly, and is recurved at the anterior apex, to continue as the slender procoracoid cartilage.

Pelvic arch. Three elements fused into one, as in the preceding genera, the distal elements forming a suboval plate; the ilium a short, curved rod, articulating proximally with a single robust diapophysis of a single vertebra. The whole structure is entirely lateral.

Observations. Duméril and Bibron commit an error in their figure of the pelvis of the Anguis fragilis, in representing the pelvic elements as meeting on the middle line below, which is far from being the case. Fürbringer's figures are much more accurate.

Comparison of Diploglossa. The degeneracy in this series is tolerably consistent in the order of its progress. In none of the genera are fore limbs present, and in three of them hind limbs are present. Notwithstanding the universal absence of fore limbs, a scapular arch is always present. This region shows, however, successive stages of degeneracy, as follows: In the three genera without posterior limbs, the sternum has costal articulations; in the other three, none. In the genera with costal articulations, the number of the latter diminishes regularly: in Mancus, three ; in Opheodes, two; in Pygopus, one. Of the three genera with costal articulations, the interclavicle is present in two; in one (Pygopus) it is wanting. In the other genera it is present in a much modified form and position in one genus (Ophisaurus). Clavicles and coracoids are osseous in all of them; but the procoracoid is osseous in only two genera (Opheodes and Pygopus); while in the third genus with 
costal articulations (Mancus), it is cartilaginous, as in the genera without costals. The genera with costal articulations are also the only ones with osseous scapula. So we observe a certain order in the loss of parts. Thus, the part to disappear first is the interclavicle (to reappear in Ophisaurus); second, costal articulations and osseous scapula; third, sternum, which diminishes in size until greatly reduced as in Anguis and Dopasia.

As regards the pelvic arch, reduction of its elements precedes the loss of limbs. Thus, Mancus is the only genus where the pubis and ischium meet (or in the ischium, are connected by an osseous hypogastroid) on the middle line. In Opheodes, where the posterior limbs are much as in Mancus, these elements are separated below the pubes widely. In Pygopus, where the limbs are better developed than in either, the inferior pelvic elements are rudimental and widely separated, being merely processes of the ilium. In the genera without limbs (Ophisaurus with a minute rudiment), this reduction is carried still further, the inferior elements not being distinguished from each other or from the ilium, the entire arch having a lateral position. Müller remarks of these parts in Pseudopus, Ophisaurus, and Anguis, that they are "zwar sehr ähnlich." The order of degeneracy, then, in the pelvic appendages in the Dip$\operatorname{loglossa}$, is, first, reduction of inferior pieces; second, loss of limbs; third, fusion of all the elements into a single lateral bone.

\section{LEPTOGLOSSA.}

TEIDE.

Propus vermiformis Cope. Pl. XIII, Fig. io. From the Upper Amazon in Equador. Not previously examined.

Scapular and pelvic arches present; anterior limbs only, and these minute.

Scapular arch. All the elements present, but the sternum represented by a narrow longitudinal cartilage, and the interclavicle without lateral processes. Clavicle osseous, distally simple; suprascapula cartilaginous ; scapula and coracoid, osseous. Coracoid deeply twice emarginate, the emarginations occupied by the coracoid cartilage. Sternum with two costal articulations. Fore limbs consisting of humerus and rudimental ulnoradius. 
Pelvic arch. This consists of a simple slender costiform bone, directed downwards and forwards from the diapophysis of a single vertebra. It is homologous wholly or in part with the ilium.

\section{SCINCIDÆ.}

Dr. Boulenger remarks as to this family: "I have met with great difficulty in arranging the genera of this family. The majority of the characters hitherto employed for the distinction of genera, such as the degree of development of the limbs, the presence or absence of a transparent disk in the lower eyelid, the presence or absence of keels or scales, etc., are in many cases not even of specific value. I have therefore used certain characters which hitherto have been neglected, but which, I am convinced, afford a firmer basis for a natural arrangement. The artificial nature of an arrangement based on the degree of the development of the limbs has been pointed out by others. In a family like the Scincoids, in which the limbs are undergoing a process of abortion, this character must be abandoned as one expressing relationship by itself. And I trust that the arrangement of the species in one or more series within a genus, passing from forms with well-developed pentadactyle limbs and lacertiform physiognomy to such as have rudimentary limbs, or even none at all, marks a great improvement upon the artificial classifications in use down to the present day."

I am not prepared to admit that the above remarks of Dr. Boulenger have more than an application to the cases when the development of the limbs and digits is irregular in the same species. This has not been shown to be the case more frequently than we expect to find in all other zoölogical characters, and particularly in those which we call generic. It is, indeed, precisely the grades of characters expressed by the last structural modifications of parts that the generic nomenclature is created to record. So long as the characters are constant, then, it is necessary to designate them by generic terms, and I have therefore adopted in the following synopsis of genera those which have been proposed by my predecessors for the various degrees of development of the limbs and toes. In doing so, however, I have adopted the primary divisions proposed by Dr. Boulenger, as it is clear that they have a higher value than those based on the number of digits, etc. 


\section{Synopsis of Genera.}

I. Nostril pierced in the nasal, or between the nasal and supra- or postnasal or first upper labial, not touching the rostral.

$A$. Palatine bones separated on the median line of the palate; no supranasal shields.

No azygos occipital shield;

Egernia Gray.

An azygos occipital shield in contact with the interparietal; tail prehensile;

Corucia Gray.

$A A$. Palatine bones in contact on the median line of the palate.

I. Tympanum, if distinct, more or less deeply sunk.

a. Pterygoid bones separated on the median line of the palate, the palatal notch extending anteriorly to an imaginary line connecting the centre of the eyes.

\section{a. No supranasals.}

Lateral teeth with obtuse or spheroidal crowns ; an azygos occipital in contact with the interparietal; subdigital lamellæ divided; Trachysaurus Gray.

Lateral teeth with obtuse or spheroidal crowns; subdigital lamellæ undivided;

An enormous crushing tooth on each side of each jaw;

Tiliqua Gray.

Hemisphariodon Ptrs.

$\beta$. Supranasals present.

Lateral teeth with compressed, denticulated crowns; a series of suborbital shields ;

Lateral teeth conical; two frontoparietals ;

Lateral teeth conical; one frontoparietal ;

Macroscincus Bocage.

Mabuia Fitz.

Monophyaspis Cope.

b. Pterygoids in contact (at least quite anteriorly) mesially, the palatal notch not extending anteriorly to between the centre of the eyes.

* Eyelids movable; digits with non-retractile claws.

† Supranasal plates present (tympanum not concealed).

$\ddagger$ Lower eyelid with a transparent disk.

$\S$ Frontoparietal single.

Digits $5-5$;

Digits 5-4;

Digits $4-4$;

Digits 5-5;

Digits 2-3;

Digits 5-5 ;

Digits 5-5 ;
Emoa Gray.

Hagria Gray.

Chiamela Gray.

$\S \S$ Two frontoparietals.

Riopa Gray.

Eumecia Bocage.

ł Lower eyelid scaly.

$\S$ Frontoparietal single.

§§ Two frontoparietals.

Monophorus Cope.

Lepidothyris Cope.

$\dagger \dagger$ Supranasal plates wanting.

$\ddagger$ Lower eyelid with a transparent disc.

I| Tympanum not concealed.

$\S$ Frontoparietal plate single. 
Digits 5-5 ;

Digits 4-5;

Digits $\mathrm{I}-2$;

Digits I-I ;

Digits O-2 ;

Digits O-I ;

Digits 5-5;

Digits 3-3;

Digits I-2;

Digits 5-5;

Digits 4-4;

Digits 3-3;

Digits 2-2;

Digits 5-5;

Digits 5-5;

Digits 5-5;

Digits 3-I ;

Digits 5-5;

Digits 3-3;

Digits 2-2;

Digits I-I ;

Digits $0-0$;
§ Frontoparietal plate double.

$$
\begin{array}{r}
\text { Mocoa Gray. } \\
\text { Heteropus D. \& B. } \\
\text { Brachystopus D. \& B. } \\
\text { Oncopus Cope. } \\
\text { Ollochirus Cope. } \\
\text { Soridia Gray. }
\end{array}
$$

Liolepisma D. \& B. Tridentulus Cope. Furcillus Cope.

||| Tympanic meatus closed. § Frontoparietal single.

§ Frontoparietals distinct.

Haploscincus Cope.

Tetradactylus Merr. Hemiergis Wagl. Chelomeles D. \& B.

ł Lower eyelid scaly.

|| Tympanic meatus not closed.

$\S$ Frontoparietal single.

$\S \S$ Frontoparietals two.

||| Tympanic meatus closed.

$\S$ Frontoparietal single.

Lygosoma Gray.

Homolepida Gray.

Cophoscincus Pet. Anomalopus D. \& B.

$\S \S$ Frontoparietals distinct.

Nannoscincus Günth. Siaphus Gray. Dimeropus Cope. Coloscincus Pet. Opheoscincus Pet. ** Eyelids immovable, transparent, covering the eye.

† Supranasals present. Two frontoparietals; ear exposed.

Digits 5-5;

$\dagger \dagger$ No supranasals.

Panaspis Cope.

|| Two frontoparietals (ear not closed).

Digits 5-5;

Digits 4-4;

Digits $3-3$;

Digits $2-3$;

Digits 5-5;

Digits 4-4;
Cryptoblepharus Wiegm.

Menetia Gray.

Ablepharus Fitz. Miculia Gray. Phaneropis Fischer. Lerista Gray.

||| One frontoparietal.

$\S$ Ear exposed.

$\S \S$ Ear concealed.
Blepharactisis Hallow. 
Digits $5-5$

Blepharosteres Stolicz.

*** Eyelids movable; claws retractile into a sheath.

Digits 4-5;

Ristella Gray.

Head normal.

2. Tympanum exposed and superficial.

$A A A$. Palatine bones separated on the median line; supranasal shields present.

Nostril pierced in the nasal; pterygoid bones toothed; limbs pentadactyle, the digits not denticulated laterally;

Eumeces Wiegm.

Nostril pierced in a very small nasal, between the rostral, the first labial, the supranasal, and sometimes a postnasal; palate toothless; digits 5-5; limbs short ;

Senira Gray.

Like Senira, but limbs rudimentary, undivided; Brachymeles D. \& B.

Nostril pierced between an upper and a lower nasal; limbs pentadactyle, the digits denticulated laterally;

Scincus Laur.

Nostril pierced between the nasal and supranasal; digits 4-3;

Like Zygnopsis, but digits 3-3;

Zygnopsis Blfd.

Like Zygnopsis, but digits $3^{-2}$;

Sphenoscincus Pet.

Like Zygnopsis, but limbs absent;

Hemipodium Steind.

Opheomorus D. \& B.

II. Nostril pierced in the posterior border of the rostral, or between a nasal or a labial and the rostral.

A. Palatine bones in contact on the median line.

Nostril pierced between the rostral and a very small nasal, which may be reduced to a narrow ring.

Digits $5-5$; frontoparietal distinct;

Digits $5-5$; no frontoparietals or prefrontals ;

Digits 3-3;

No fore limbs; hind limbs didactyle;

No fore limbs; hind limbs undivided;

No limbs externally;

A.A. Palatine bones separated on the median line.

I. Supranasals present; first upper labial not touching the nostril.

* Nostril pierced between the rostral and a very small nasal in an emargination of the former shield.

Digits 5-5;

a. Labial border rounded.

Digits 4-4;

Digits 3-4;

Digits 2-4;

Digits 3-3;

Digits 2-3;

Digits I-I (limbs undivided);

Thyrus Gray. Amphiglossus D. \& B. Sepomorphus Pet.

Scelotes Fitz.

Podoclonium Cope. Herpetosaura Pet.

Digits 5-5-4-4;

aa. Labial border projecting; acute.

** Nostril pierced between the rostral and a very small nasal, which is situated between the former shield and the first labial. 
No limbs ;

Herpetoseps Blgr.

2. Supranasals present; first upper labial entering the nostril.

* Nostril pierced between the rostral, the supranasal, the postnasal, and the first labial; no frontoparietals.

Digits 5-5;

Digits $4-4$;

Digits 3-3;

No fore limbs; hind limbs undivided;

** Nostril pierced between the rostral, the supranasal, and the first labial; frontoparietals present.

Limbs absent;

3. No supranasals; nostril entirely in the rostral.

Digits 4-4;

Mesomycterus Cope. Rhinoscincus Peters.

Sepsina Bocage.

Dumerilia Bocage.

Sepophis Bedd.

Chalcidoseps Blgr.

Chalcides lineatus Leuckart. Pl. XIII, Fig. 8. Not previously examined, but the closely allied $C$. tridactylus is described and figured by Fürbringer. ${ }^{1}$

Scapular and pelvic arches present. Limbs of both pairs present, very short, with digits $3-3$.

Scapular arch. All the elements present, and presenting the true characters of the Leptoglossa; viz. clavicles distally dilated and perforate, and interclavicle cruciform. The scapula and coracoid are fused and osseous. The coracoid cartilage encloses a coracoid foramen, and coraco-procoracoid foramen with the cartilaginous procoracoid. Suprascapula large, cartilaginous. Sternum well developed, with cartilaginous borders, no foramen, and four costal articulations.

Pelvic arch. All the elements present, but slender; the inferior arches directed anteriorly; the pubes in contact distally. The ischia are separated by a narrow membrane, which extends forward to the pubic symphysis. The ilium stands nearly vertical, its inferior portion articulating with the distally fused extremities of the diapophyses of two vertebræ. Except in the slenderness of its parts, the pelvis is like that of Scincidæ with well developed limbs.

Fürbringer represents only three sterno-costal articulations in the $C$. tridactylus.

\section{Acontilde.}

Evesia monodactyla Gray. Pl. XIII, Fig. 9. From Ceylon. Not previously examined.

${ }^{1}$ Loc. cit., Pl. I, Fig. 3; Pl. III, Figs. 26-7. 
Scapular and pelvic arches present. Anterior and posterior limbs present, external, very rudimental, and undivided.

Scapular arch. All the elements present. Sternum cartilaginous, with two costals; clavicles osseous, proximally simple. Interclavicle a simple, longitudinal, bony splint. Scapula and coracoid distinct ; only ossified on their posterior borders. Coracoid and procoracoid cartilages not distinct, nor enclosing any fontanelles. Anterior limb consisting of a humerus with a minute cubital segment.

Pelvic arch. Elements present subequal ; the inferior directed forwards, meeting on the middle line, without longitudinal connection. Ilium directed slightly forwards and upwards, and articulating by its proximal extremity with the fused distal extremities of the diapophyses of two vertebræ. Posterior limb exactly like the anterior; i.e. consisting of a proximal element (femur) and a distal rudimental segment.

Fürbringer, l.c., describes and figures the shoulder and pelvic girdles of Acontias meleagris and A. plumbeus. The shoulder girdles consist of simple elements supposed to represent scapulæ, fused or not on the middle line, the median portion of which, in the $A$. plumbeus, it is suggested, may be clavicles. The pelvic girdles consist, in both species, of a simple element on each side, consisting of ilium (joined to vertebræ) and supposed pubis. My examination of Evesia shows the impropriety of combining that genus with Acontias, as has been done by Boulenger.

\section{Anelytropside.}

Anelytropsis papillosus Cope. Pl. XIII, Fig. il. From Eastern Mexico. Not previously examined.

No scapular arch; pelvic arch rudimental; no external limbs.

Pelvic arch. This is represented by two elements, - a proximal and a distal. The former is directed downwards and forwards. Its proximal extremity is articulated with a single simple diapophysis, from which it extends a short distance posteriorly in a horizontal direction as far as the posterior extremity of the centrum of the same vertebra. From the inner side of its distal extremity there extends posteriorly a simple rod-like bone, to a point in line with the anterior margin of the vent. Its length is about equal to that of the superior element. 
The superior element is ilium, but the inferior does not appear to be either pubis or ischium. Its position and direction are not inconsistent with its identification with the femur; but as it occurs in snakes, which have a rudimental femur, it cannot be that bone.

Observations. The inferior element in the pelvis in this genus is the same as that which I described as occurring in the African form of this family, Feylinia (Anelytrops Hallow.), but the latter differs in the absence of the rib-like ilium. It is interesting to notice the resemblance between these genera, which are so widely removed geographically. Feylinia, however, differs further from Anelytropsis in the presence of a pair of clavicles (loc. cit.).

Feylinia curroril Gray. Described by me (Proceed. Acad., Phila., I 864, p. 230).

Scapular arch. This consists of a pair of osseous clavicles which nearly meet on the median line. The anterior ribs to

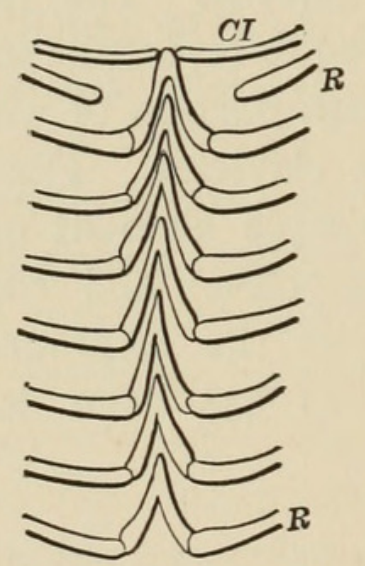

FIG. I.

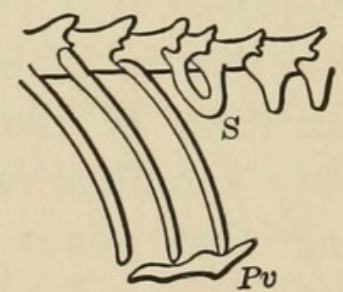

FIG. 2.

Fig. I. Sternal region in Feylinia currorii Gray. From West Africa. Cl, clavicles; $R R$, ribs. Fig. 2. Pelvic element and adjacent part of vertebral column. $S$, sacrum; $P v$, pelvic element.

the number of seven pairs meet on the median line by their cartilaginous hæmapophyses, which are directed forwards at an acute angle, the angle of the anterior pair intervening between the clavicles.

Pelvic arch. This consists of a single element lying on each side of the vent antero-posteriorly, perhaps homologous with the corresponding element in the Annulati. It is in contact with the distal extremities of three ribs, and is connected by 
ligament with a third anterior to them. These are the last ribs, and they are followed by a pair of sacral vertebræ whose diapophyses are united distally.

Remarks. This pelvic element is probably the iliopectineal element of Fürbringer. The pelvis differs from that of Anelytropsis (antea) in the absence of iliac element.

Comparison of the Leptoglossa. In Chalcides we have nearly normal scapular and pelvic arches, while the limbs are very much reduced, though not to be termed rudimental. In the next stage of reduction, where all the limbs are present, but rudimental, the two arches show a considerable degradation, which is more marked in the scapular than in the pelvic. The pelvic elements remain much as in Chalcides, but reduced in size merely. In the scapular arch, the sternum loses two costals, and the interclavicle loses the transverse processes. The clavicles become simple, and the ossification of the scapula and coracoid is reduced in extent. In Propus, where the fore limbs are much as in Evesia, while the hind limbs have disappeared, the scapular arch has many points in common with Evesia. Thus, the clavicle and interclavicle are simple, and the sternum has only two costals. The scapular and clavicle are much better ossified. On the other hand, the pelvic arch displays a great reduction. In Anelytropsis, appropriately to the absence of fore limbs, there is no scapular arch. The pelvic arch is greatly reduced; but, curiously, there appears an element which resembles a corresponding element in the snakes. This arrangement is quite different from anything observed in the other Leptoglossa or in the Diploglossa, but is not without parallel in other Lacertilia, to be described later on.

The reduction of the scapular elements proceeds in the Leptoglossa on much the same lines as observed in the Diploglossa. The early simplification of the distal end of the clavicle is peculiar to the Leptoglossa, as it is always simple in the Diploglossa. The late stages of reduction of the sternum seen in the limbless Diploglossa are not exhibited by any of the forms here described, although they probably exist, since we have the Anelytropsis, where the scapular arch is wanting. On the other hand, the extreme reduction of the pelvis seen in Propus, where the ilium only remains, has not been yet observed in the Diploglossa without posterior limbs (Figs. 4, 5, 6). 


\section{ANNIELLOIDEA.}

\section{AnNiellidæ.}

Anniella pulchra Gray. Pl. XIII, Fig. 7. From Southern California. Not previously examined.

Scapular arch wanting; pelvic arch rudimental; no limbs. The pelvic arch is represented by a small and short rod-like bone, which is attached to the extremity of the diapophysis of a single vertebra. The proximal extremity is directed backwards for a short distance posterior to the point of suspension, as in Anelytropsis. No traces of inferior elements or of posterior limb. This is the most rudimental ilium yet encountered.

\section{ANNULATI.}

\section{Chirotide.}

Chirotes Canaliculatus Bonnat. Pl. XIII, Fig. I2. Lower California. Described and figured by Müller, l.c., Pl. XXI, Figs. II, I2 ; and by Duméril and Bibron, Erpétologie Générale, Atlas, Pl. VII, Figs. I, 2 ; both with omission of pelvic arch.

Scapular and pelvic arch present; fore limbs, but no hind limbs.

Scapular arch. For the first time in the history of scapular reduction, we find the clavicle absent. No interclavicle nor procoracoid. Supraclavicle osseous. Clavicle and coracoid osseous, coössified ; no coracoid cartilage. Sternum without costals, osseous, pentagonal, and with a long xiphoid process. Ulna and radius well distinguished. Pelvic arch an elongate element on each side, directed downwards and a little forwards, principally ilium, but with a short free distal extremity which represents one or both of the inferior elements. A short curved cartilage represents the femur. The ilium is connected by a cartilage with the extremity of a single diapophysis; and a short free segment corresponding to this cartilage articulates with the vertebra which follows.

Observations. Müller gives an excellent figure of the scapular arch of this species, but he says that the clavicle and scapula are fused into a single piece. This is probably an error, as there 
is apparently no clavicle, as may be seen by comparing the figures given in the present paper. Neither Müller nor Duméril and Bibron detected the rudimental pelvic arch. This appears to have been for the reason that they studied only a dried skeleton preserved in the Museum of Paris, from which this part had been lost by the preparateur.

\section{Аmphisbenidæ.}

Amphisbeena occidentalis Cope. Pl. XIII, Fig. I3. Western Peru. Not previously described.

No scapular arch nor limbs; a rudimental pelvic arch. Pelvic arch. This consists, in this species, of a slender bone in the abdominal wall, a little in front of the vent on each side, which is directed forwards and inwards, but without meeting its mate on the middle line. It has no articular connection with any other element. In Amphisbana alba this element is similar, but is relatively shorter and more as figured by Fürbringer in the $A$. fuliginosa. This species has also, according to Fürbringer, a very rudimental scapula.

Rhineura FloRIDANa Baird. Pl. XIII, Fig. I4. Florida. Not previously examined.

No scapular arch nor limbs; rudiments of a pelvic arch. Pelvic arch. This consists, as in the species of Amphisbæna, of a single, simple, bony rod on each side of the vent. It is more longitudinal in position than the corresponding element in Amphisbæna. It resembles somewhat the corresponding parts (figured by Fürbringer) in the Lepidosternum microcephalum.

Observations on Annulati. The wide diversity between the pelvic structure in Chirotes, as compared with that of Amphisbæna, emphasizes the evidence furnished by the scapular arch, in favor of regarding it as representing a family distinct from the Amphisbænidæ. Even with the pelvic elements of Chirotes before us, it is difficult to be sure of the homology of the corresponding part in Amphisbæna and Rhineura. It can only be one of the two inferior elements, or femur. Against the latter supposition, which is suggested by the structure of the Anelytropsidæ, its anterior position is strong evidence. For the reason that it approximates closely the vent, its claim to be ischium is rather stronger than the supposition that it can be 
pubis. It is homologized by Fürbringer with the iliopectineal bone of the snakes.

\section{GENERAL CONCLUSIONS.}

One conclusion is obvious, and this is, that degeneracy of the scapular and pelvic arches follows degeneracy and loss of limbs, sooner or later. More special conclusions may be expressed as follows :-

I. Anterior limbs have disappeared more generally than the posterior in the Diploglossa.

II. The limbs incline to degenerate and disappear more nearly pari passu in the Scincidæ.

III. The anterior limbs have a tendency to persist longer in the Teidæ and Amphisbænidæ. Future research may not sustain this proposition.

IV. The degeneracy in the scapular arch is delayed long after the degeneracy and loss of the anterior limbs.

V. Degeneracy of the pelvic arch precedes the loss of the pelvic limb.

VI. The order of degeneracy of the elements of the scapular arch is: (I) limb ; (2) interclavicle (generally) ; (3) costal attachment ; (4) sternum.

VII. The order of disappearance of parts in the pelvis is : (I) pubis and ischium together (generally; cf. Amphisbæna); (2) limb ; (3) ilium. 


\section{EXPLANATION OF PLATE.}

For the specimens represented in the figures I am indebted as follows: to the United States National Museum for Pygopus lepidopus, Chalcides lineatus, and Chirotes canaliculatus; to the Philadelphia Academy of Natural Sciences for Mancus macrolepis, Feylinia currorii, and Evesia monodactyla. The remaining nine species are from my private collection.

\section{Plate XIII.}

Fig. I. Mancus macrolepis Cope. From Natal. $\times 2$.

Fig. 2. Opheodes striatus Spix. From Brazil. Figs. $a, b$, and $c, \times 2$. Fig. $d$, $\times 3$. Fig. $a$, scapular arch from below. Fig. $b$, pelvic arch and adjacent vertebræ from the side. Fig. $c$, pelvic arch from below. Fig. $d$, posterior limb.

FIG. 3. Pygopus lepidopus Lacep. From Australia. $\times 2$.

FIG. 4. Ophisaurus ventralis L. From Texas. $\times 2$.

FIG. 5. Dopasia gracilis Gray. From N. India. $\times 2$.

FIG. 6. Anguis fragilis L. From Lago Maggiore, Italy. $\times 2$.

Fig. 7. Anniella pulchra Gray. From San Diego, California. $\times 3$.

FIG. 8. Chalcides lineatus Leuck. From Morocco. $\times 2$.

Fig. 9. Evesia monodactyla Gray. From Ceylon. $\times 3$.

Fig. Io. Propus vermiformis Cope. From Amazonian Equador. $\times 3$.

Fig. II. Anelytropsis papillosus Cope. From Jalapa, Mexico. $\times 3$.

Fig. 12. Chirotes canaliculatus Bonnat. From La Paz, Lower California. $\times 3$.

FIG. 13. Amphisbana occidentalis Cope. From Jequetepeque, Peru. $\times 2$.

FIG. I4. Rhineura floridana Baird. From Florida. $\times 2$.

\section{LETTERING.}

$\mathrm{Cl}$, Clavicle. Icl, Interclavicle. SSc, Suprascapula. Sc, Scapula. Co, Coracoid. $P C o$, Procoracoid. St, Sternum. Xi, Xiphisternum. Il, Ilium. Pb, Pubis. Is, Ischium. $\mathrm{Fe}$, Femur. T, Tibia. $\mathrm{Fi}$, Fibula. $\mathrm{Eg}$, Epigastroid. $\mathrm{Hg}$, Hypogastroid. 

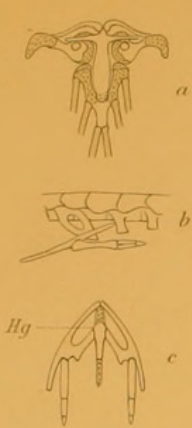

4.
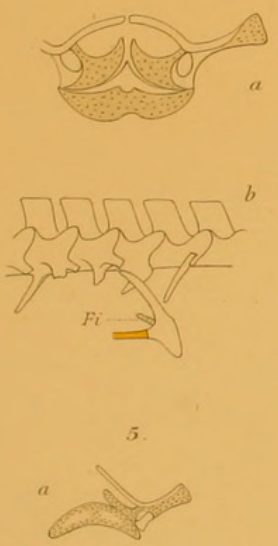

1

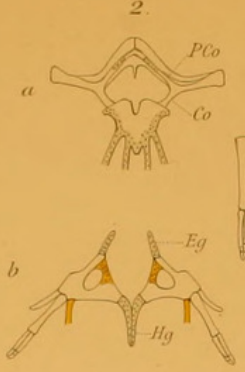

- सकाइएक
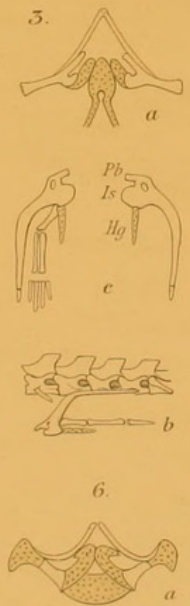

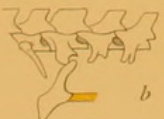

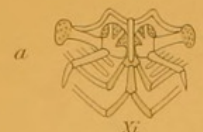

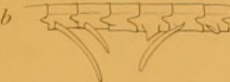

PCo

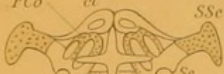

a $\sqrt{\mathrm{C}}$

a 0 onst

b द्याँचा Pb $\int_{l s} F_{F e} \frac{F_{i}}{T}$
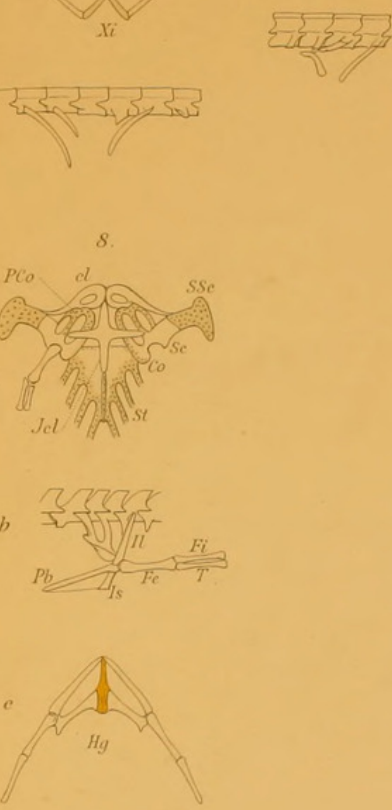

$$
b \text { दूत्त }
$$

-

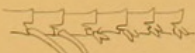

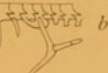

anc.

a.

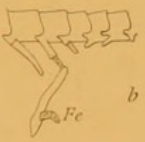

15.
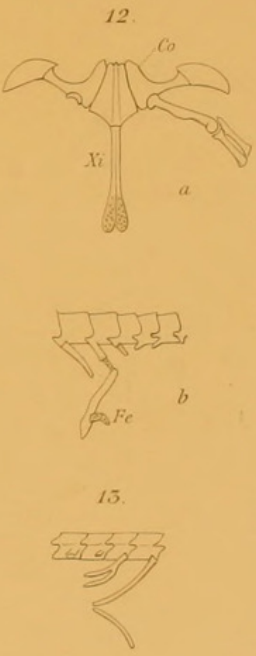

(n)




\section{$2 \mathrm{BHL}$ Biodiversity Heritage Library}

Cope, E. D. 1892. "On degenerate types of scapular and pelvic arches in the lacertilia." Journal of morphology 7, 223-244.

https://doi.org/10.1002/jmor.1050070204.

View This Item Online: https://www.biodiversitylibrary.org/item/43591

DOI: https://doi.org/10.1002/jmor.1050070204

Permalink: https://www.biodiversitylibrary.org/partpdf/92326

\section{Holding Institution}

MBLWHOI Library

\section{Sponsored by}

MBLWHOI Library

\section{Copyright \& Reuse}

Copyright Status: NOT_IN_COPYRIGHT

This document was created from content at the Biodiversity Heritage Library, the world's largest open access digital library for biodiversity literature and archives. Visit BHL at https://www.biodiversitylibrary.org. 